\title{
Oxygen and carbon dioxide fluxes at the water- sediment interface of a tropical lagoon
}

\author{
Guy Boucher $^{1}$, Jacques Clavier ${ }^{2}$, Claire Garrigue ${ }^{3}$ \\ ${ }^{1}$ URA CNRS $699 \mathrm{BIM}$, Muséum national d'Histoire Naturelle, 57 rue Cuvier, F-75231 Paris, France \\ ${ }^{2}$ Centre ORSTOM de Brest, Centre Océanologique de Bretagne, BP 70, F-29280 Plouzané, France \\ ${ }^{3}$ Centre ORSTOM, BP A5, Nouméa, Nouvelle-Calédonie (TOM), France
}

\begin{abstract}
Oxygen demand, carbon dioxide release and total alkalinity shift were calculated from changes in oxygen, $\mathrm{pH}$ and total alkalinity produced by bottom dark incubations at the water-sediment interface of the 3 bottom types identified in a southwest lagoon in New Caledonia. Total sediment oxygen demand $\left(\Delta \mathrm{O}_{2}\right)$ was corrected from nonbiological oxygen demand (NBOD) in order to obtain the apparent biological activity $\left(\Delta \mathrm{O}_{2}{ }^{\circ}\right)$. Total carbon dioxide flux $\left(\Delta \mathrm{CO}_{2}\right)$ was corrected from total alkalinity shift in order to estimate organic carbon processes. The resulting mean carbon dioxide flux $\left(\Delta \mathrm{CO}_{2}^{\circ}=\right.$ $\left.2.58 \mathrm{mmol} \mathrm{m} \mathrm{m}^{-2} \mathrm{~h}^{-1}, \mathrm{SE}=0.12\right)$ exceeded biological oxygen demand $\left(\Delta \mathrm{O}_{2}{ }^{\circ}=1.60 \mathrm{mmol} \mathrm{m}^{-2} \mathrm{~h}^{-1}, \mathrm{SE}=\right.$ 0.08). The highly significant ratio estimates from functional regression lines of $\Delta \mathrm{CO}_{2}{ }^{\circ}$ on $\Delta \mathrm{O}_{2}$ and $\Delta \mathrm{CO}_{2}{ }^{\circ}$ on $\Delta \mathrm{O}_{2}{ }^{\circ}$ gave a total community respiratory quotient (CRQ) of 1.17 ( $\mathrm{SE}=0.06$ ) and an organic respiratory quotient $\left(\mathrm{CRQ}^{\circ}\right)$, involving only direct biological processes, of 1.42 ( $\left.\mathrm{SE}=0.07\right)$ for the lagoon. The significance and the use of these ratios are discussed in order to calculate the anaerobic metabolism proportion ( $40.3 \%$ of total metabolism for an aerobic respiratory quotient of 0.85 ). Thus, the simultaneous measurement in the field of $\mathrm{O}_{2}$ fluxes and $\mathrm{CO}_{2}$ fluxes, corrected from appropriate alkalinity changes, allows a rapid approach for estimating carbon production the water-sediment interface of undisturbed communities.
\end{abstract}

KEY WORDS: Carbon flux $\cdot$ Metabolism $\cdot$ Tropical lagoon

\section{INTRODUCTION}

Although bottom oxygen uptake has been used to estimate rates of organic matter consumption by benthic organisms and oxidation of organic material, total oxygen demand of sediment alone is inadequate to estimate total benthic metabolism (Pamatmat 1977). Organic matter decomposition can occur without oxygen as a terminal oxygen acceptor and an appreciable part of the metabolism proceeds through pathways of nitrate, manganese, iron, and sulfate respiration (Jørgensen 1977, Sørensen et al. 1979). Anaerobic respiration through chemical oxidation, including what is called 'chemical oxygen demand', contributes to the total oxygen demand and depends on the balance of electron acceptors in the sediment (Anderson et al. 1986).

Total carbon dioxide, as free $\mathrm{CO}_{2}$ or $\mathrm{HCO}_{3}{ }^{-}$, is released into interstitial water and overlying water during aerobic respiration and all anaerobic processes (e.g. nitrate and sulphate reduction, methanogenesis fermentations) because natural assemblages of bacteria are net carbon dioxide producers (Marty et al 1989). In order to relate total sediment oxygen demand $\left(\Delta \mathrm{O}_{2}\right)$ to biological carbon dioxide production $\left(\Delta \mathrm{CO}_{2}{ }^{\circ}\right)$ at the water-sediment interface, the total community respiratory quotient $\left(\mathrm{CRQ}=\Delta \mathrm{CO}_{2}{ }^{\circ} / \Delta \mathrm{O}_{2}\right)$ is usually measured. This value is useful in stoichiometric calculations related to decomposition processes and it characterises whole ecosystem or community metabolism where both aerobic and anaerobic respiration and chemical oxidation occur simultaneously (Andersen \& Kristensen 1988). It is generally considered that simultaneous measurement of carbon dioxide release and oxygen demand in dark incubations of marine sediments allows the calculation of an integrated measure of aerobic respiration, nitrate and sulphate respiration and methanogenesis (Hargrave \& Phillips 1981, Andersen \& Hargrave 1984, Kepkay \& Andersen 1985). 
A field method was developed in the southwest lagoon of New Caledonia to (1) determine the community respiratory quotient considered as a conversion factor to transform oxygen demand to carbon fluxes, and (2) estimate the relative importance of benthic aerobic and anaerobic metabolisms at the water-sediment interface of undisturbed communities.

\section{MATERIAL AND METHODS}

Study site. During a cruise of the OV 'Alis', bottom incubation experiments and sample collections were carried out at 14 stations (Fig. 1) in the southwest lagoon of New Caledonia from 10 to 20 December 1991 and from 6 to 9 January 1992 (Garrigue et al. 1992b). Depths ranged from 6.7 to $17.0 \mathrm{~m}$. Bottom water temperature varied from 23.78 to $27.78^{\circ} \mathrm{C}$. Salinity ranged from 35.55 to $36.01 \%$. Sampling sites were located in communities previously defined as mud deposits (5 stations), grey-sand bottoms (6 stations) and whitesand bottoms (3 stations), which represented 35, 50 and $15 \%$ respectively of the lagoon bottom (Chardy et al. 1988). At each station triplicate enclosure experiments simulating dark conditions were performed.
Incubation procedure. Oxygen and carbon dioxide fluxes at the water-sediment interface were simultaneously measured in the water trapped in enclosures according to the incubation methods described in Boucher \& Clavier (1990). Three replicate PVC cores $\left(0.2 \mathrm{~m}^{2}\right)$ were pushed by SCUBA divers ca $10 \mathrm{~cm}$ into the sediment at a distance of $1 \mathrm{~m}$ from each other. The openings of the cores were then sealed with clear acrylic hemispheres to trap a known volume of bottom water, varying from 51.8 to $64.5 \mathrm{l}$ according to the depth of core insertion into the substrate. Injection of a chemical photosynthesis inhibitor (DCMU) into the enclosures $\left(5 \times 10^{-5} \mathrm{~mol}^{-1}\right)$, according to a procedure described by Garrigue et al. (1992a) allowed the measurement of respiration at ambient light. Gusher galley pumps ensured a gentle closed-circuit flow, allowing good mixing of the water trapped in the incubation chambers without particulate resuspension. Incubations began at 09:00 $\mathrm{h}$ after oxygen and $\mathrm{pH}$ logger calibrations and underwater deployment of the enclosures and lasted $5 \mathrm{~h}$ until 14:00 h, a duration producing no critical oxygen depletion ( $<80 \%$ saturation), which could have modified linear oxygen demand.

Nonbiological oxygen demand (NBOD) experiments were carried out on 15 incubations. Each enclosure

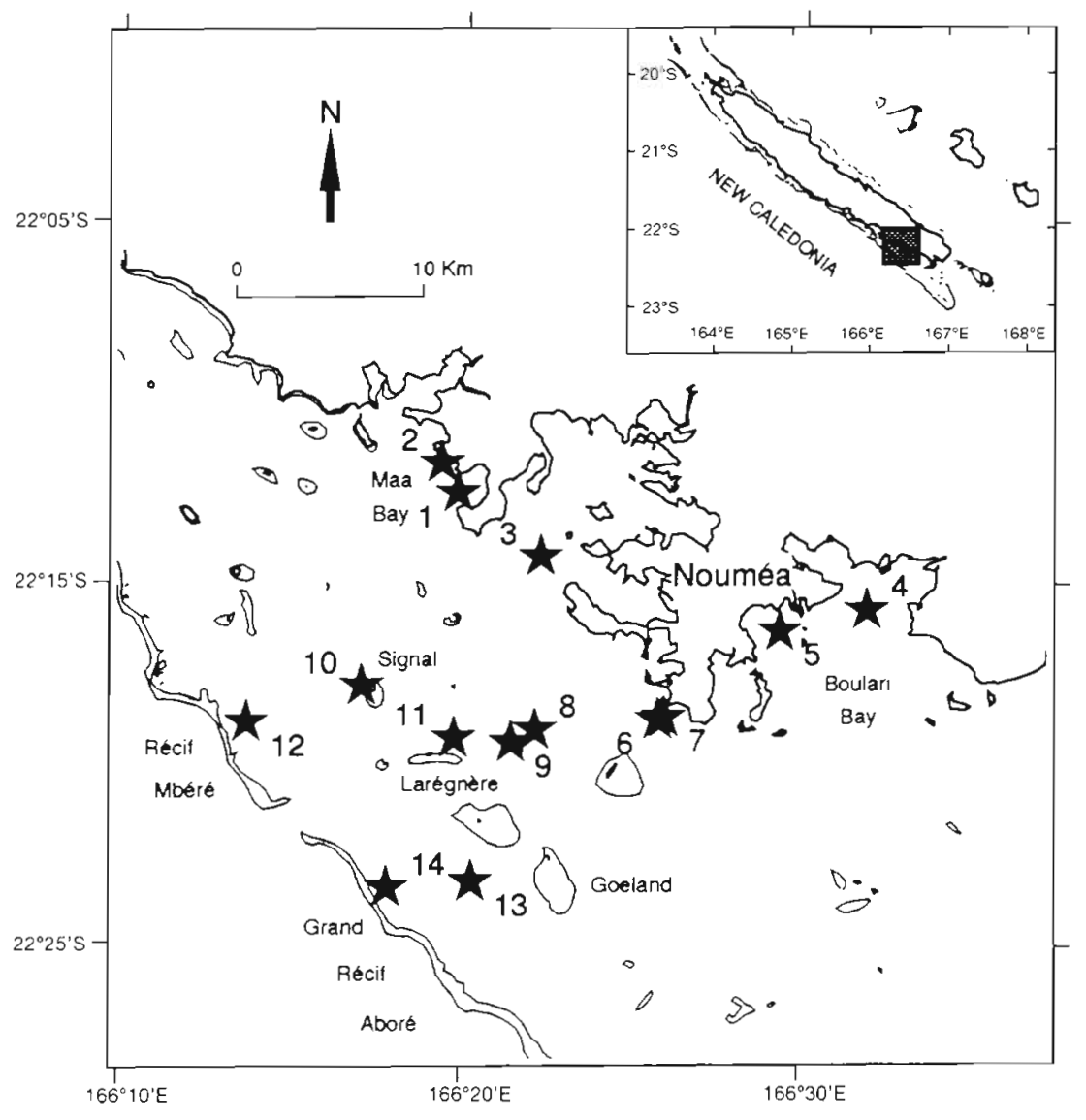

Fig. 1. Location of sampling sites in the southwest lagoon of New Caledonia. Mud deposits (with depth) are:

1: Maa Bay I, $12 \mathrm{~m}$;

2: Maa Bay II, $13 \mathrm{~m}$;

3: Dumbea Bay, $17 \mathrm{~m}$;

4: Boulari Bay, $14 \mathrm{mi}$

5: Magenta Bay, $14 \mathrm{~m}$

Grey-sand bottoms are:

6: Rocher à la Voile $\mathrm{I}, 10 \mathrm{mi}$

7: Rocher à la Voile II, $10 \mathrm{~m}$;

8: Sèche Croissant I, $10 \mathrm{~m}_{\text {i }}$

9: Sèche Croissant II, $15 \mathrm{~m}$;

10: Signal, $17 \mathrm{~m}$;

11. Larégnère, $16 \mathrm{~m}$.

White-sand bottoms are:

12: Récif Mbéré II, $12 \mathrm{~m}$;

13: Goeland, $12 \mathrm{~m}$;

14: Grand Récif Aboré, $15 \mathrm{~m}$ 
received an injection of $4 \mathrm{l}$ of $40 \%$ neutralised formalin in order to obtain a ca 2.5 to $3 \%$ dilution which stops biological activity $\left(\Delta \mathrm{O}_{2}{ }^{\circ}\right)$. Oxygen uptake was measured for $4 \mathrm{~h}$ to obtain a linear recording of NBOD. NBOD was expressed as a percentage of total oxygen demand.

Oxygen and pH loggers. Oxygen demand was recorded in situ with a 3-channel oxygen logger respirometer built by the ORSTOM Center of Nouméa (3 Yellow Spring Instrument YSI 58 oxymeters refitted in a waterproof container). Data were stored in a Squirrel analogue recorder and later transferred on board to a computer. The 3 polarographic probes were calibrated every morning in moist air.

The $\mathrm{pH}$ logger was built by the AIMS laboratory (Townsville, Australia) according to a technology developed by Barnes (1983) and later adapted by Chisholm et al. (1990) and Gattuso et al. (1993). Three Radiometer GK2401C combined pH electrodes were fitted in pressure-compensated cells connected to preamplifier boxes. pH was measured every second, and averaged and recorded every minute. Linear regression of the $300 \mathrm{pH}$ values recorded over $5 \mathrm{~h}$ was calculated. Then the $\mathrm{pH}$ values corresponding to the initial and final sampling time, when alkalinity could be measured, were calculated.

Total alkalinity. Incubation water was collected by SCUBA divers using $100 \mathrm{ml}$ syringes, at the beginning and at the end of the incubation. Samples were analysed immediately after collection. A total of $50 \mathrm{ml}$ of incubation water was injected through a Sweenex $0.8 \mu \mathrm{m}$ filter to remove particulate $\mathrm{CaCO}_{3}$ material. Total alkalinity (TA) was measured on board by the potentiometric automatic method (Culberson et al. 1970) with a Tacussel Titrator TT-processor $2600 \mathrm{~S}$ and an EBX2 $20 \mathrm{ml}$ automatic burette. Titration involved the continuous measurement of the $\mathrm{pH}$ of a seawater sample where a known volume $(15 \mathrm{ml})$ of $\mathrm{HCl} 0.01 \mathrm{~N}$ was continuously added. A total of 8 replicate measurements were performed at the beginning and at the end of each incubation, i.e. 24 samples at the start and at the finish of the experiment. Alkalinity flux $(\Delta T A$ : $\mathrm{mEq} \mathrm{m}^{-2} \mathrm{~h}^{-1}$ ) was expressed as the difference of final TA and initial TA, corrected for incubation duration and surface of the enclosure.

Flux calculation. Oxygen flux $\left(\mathrm{mmol} \mathrm{m}^{-2} \mathrm{~h}^{-1}\right)$ was expressed as the slope of the linear regression of oxygen content in the incubation water versus time. As biological oxygen demand should only include oxidation by living organisms, its flux was expressed as:

$$
\Delta \mathrm{O}_{2}{ }^{\circ}=\Delta \mathrm{O}_{2}-\mathrm{NBOD}
$$

The total $\mathrm{CO}_{2}$ concentration in the incubation water was calculated according to Strickland \& Parsons (1972), using the formula given in Oviatt et al. (1986). $\Delta \mathrm{CO}_{2}\left(\mathrm{mmol} \mathrm{m} \mathrm{m}^{-2} \mathrm{~h}^{-1}\right)$ during incubation was deter- mined by the difference of $\mathrm{CO}_{2}$ concentration at the beginning and at the end of the incubation, taking into account ambient $\mathrm{pH}$, alkalinity, temperature and salinity. This flux not only depends on organic carbon variation $\left(\Delta \mathrm{CO}_{2}{ }^{\circ}\right)$, but also on the alkalinity shift at the interface related to the dissolution and precipitation of $\mathrm{CaCO}_{3}\left(\triangle \mathrm{CaCO}_{3}\right)$, and to the consumption of electron acceptors other than molecular oxygen: $\Delta \mathrm{CO}_{2}{ }^{\circ}=\Delta \mathrm{CO}_{2}-x \mathrm{TA}$. We used $x=0.5$, as we considered that TA is only influenced by precipitation (negative flux) or dissolution (positive flux) of $\mathrm{CaCO}_{3}$, the total $\mathrm{CO}_{2}$ content of seawater being lowered or increased by $0.5 \mathrm{~mol}$ for each equivalent of TA change (Skirrow 1975, Gattuso \& Jaubert 1990, Chisholm \& Gattuso 1991), and sulphate respiration which predominates in the tropical environment (Skyring \& Chambers 1976, Kristensen et al. 1991).

The total community respiratory quotient was calculated as: $C R Q=\left|\Delta \mathrm{CO}_{2}{ }^{\circ} / \Delta \mathrm{O}_{2}\right|$. This quotient should be used to calculate carbon fluxes from total oxygen demand in sediments. In order to calculate the relative contributions of aerobic and anaerobic metabolism, oxygen fluxes must be corrected from NBOD. The organic community respiratory quotient $\left(\mathrm{CRQ}^{\circ}\right)$ is:

$$
\begin{aligned}
\mathrm{CRQ}^{\circ} & =\left|\Delta \mathrm{CO}_{2}{ }^{\circ} / \Delta \mathrm{O}_{2}{ }^{\circ}\right|=\mid\left(\Delta \mathrm{CO}_{2}^{\circ}{ }^{\circ} \text { an }+\mathrm{CO}_{2}^{\circ}{ }^{\circ}{ }_{\text {ox }}\right) / \Delta \mathrm{O}_{2}{ }^{\circ} \mid \\
& =\mid\left(\Delta \mathrm{CO}_{2}^{\circ}{ }^{\circ} / \Delta \mathrm{O}_{2}^{\circ}\right)+\left(\Delta \mathrm{CO}_{2}^{\circ} \text { an } / \Delta \mathrm{O}_{2}^{\circ}\right) \mid \\
& =\mid \mathrm{RQ}+\left(\Delta \mathrm{CO}_{2}^{\circ}{ }^{\circ} \text { an } / \Delta \mathrm{O}_{2}^{\circ}{ }^{\circ}\right) \mid \\
\mathrm{CO}_{2}{ }^{\circ} \text { an } & =\left(\mathrm{CRQ}^{\circ}-\mathrm{RQ}\right) \times\left|\Delta \mathrm{O}_{2}^{\circ}\right|
\end{aligned}
$$

where $\Delta \mathrm{O}_{2}{ }^{\circ}=$ biological oxygen demand; $\Delta \mathrm{CO}_{2}{ }^{\circ}=$ total organic $\mathrm{CO}_{2}$ flux (corrected from TA shift); $\Delta \mathrm{CO}_{2}^{\circ}{ }^{\circ}=$ $\mathrm{CO}_{2}$ flux resulting from aerobic metabolism; $\Delta \mathrm{CO}_{2}^{\circ}$ an $=$ $\mathrm{CO}_{2}$ flux resulting from anaerobic metabolism; $\mathrm{CRQ}^{\circ}=$ community respiratory quotient for organic carbon; and $R Q=$ aerobic respiratory quotient.

The proportion of anaerobic metabolism (ANQ = anaerobic quotient $\times 100$ ) was calculated as follows:

$$
\begin{gathered}
\mathrm{ANQ}=\Delta \mathrm{CO}_{2}^{\circ} \text { an } / \mathrm{CO}_{2}{ }^{\circ}=\left(\mathrm{CRQ}^{\circ}-\mathrm{RQ}\right) \times \Delta \mathrm{O}_{2}{ }^{\circ} / \Delta \mathrm{CO}_{2}{ }^{\circ} \\
\Delta \mathrm{O}_{2}{ }^{\circ} / \Delta \mathrm{CO}_{2}{ }^{\circ}=1 / \mathrm{CRQ} \\
\mathrm{ANQ}=\left(\mathrm{CRQ}^{\circ}-\mathrm{RQ}\right) / \mathrm{CRQ}^{\circ}=1-\left(\mathrm{RQ} / \mathrm{CRQ}^{\circ}\right)
\end{gathered}
$$

Statistical analysis. ANOVAs were performed on 3 groups of stations corresponding to the 3 bottom types. Multiple range tests of the relationships among variables were performed to detect homogeneous groups of stations using least significant differences (LSD), with a confidence interval of $95 \%$ (Sokal \& Rohlf 1981) Since both $\mathrm{CO}_{2}$ and $\mathrm{O}_{2}$ fluxes were subjected to natural variability and measurement errors, functional regression (Ricker 1973) was applied for metabolic quotient calculations (Jacques \& Pilson 1980, Gattuso \& Jaubert 1990). 
Table 1. Mean values (standard errors in parentheses) of carbon dioxide and oxygen demand at the 3 different bottom types of the southwest lagoon of New Caledonia: $\Delta \mathrm{CO}_{2}$ and $\Delta \mathrm{CO}_{2}^{\circ}$ : total carbon dioxide and organic carbon dioxide fluxes (mmol $\mathrm{m}^{-2} \mathrm{~h}^{-1}$ ); $\Delta \mathrm{O}_{2}$ and $\Delta \mathrm{O}_{2}^{\circ}$ : total sediment oxygen demand and biological oxygen demand ( $\mathrm{mmol} \mathrm{m} \mathrm{m}^{-2} \mathrm{~h}^{-1}$ ). W: percentage of the lagoon surface occupied by mud deposits (MD), grey-sand bottom (GSB) and white-sand bottom (WSB). Lagoon: mean value of investigated stations. Lagoon (WM): mean values corrected from the surface occupied in the lagoon (weighted mean)

\begin{tabular}{lcccccccc}
\hline Community & $\mathrm{W}$ & $\mathrm{N}$ & $\Delta \mathrm{CO}_{2}$ & $\Delta \mathrm{CO}_{2}{ }^{\circ}$ & $\Delta \mathrm{O}_{2}$ & $\Delta \mathrm{O}_{2}{ }^{\circ}$ \\
\hline $\mathrm{MD}$ & 0.35 & 15 & $1.65(0.14)$ & $1.43(0.09)$ & $-1.46(0.05)$ & $-0.84(0.06)$ \\
$\mathrm{GSB}$ & 0.50 & 18 & $3.81(0.19)$ & $3.37(0.19)$ & $-2.97(0.15)$ & $-2.22(0.14)$ \\
WSB & 0.15 & 9 & $2.79(0.21)$ & $1.98(0.42)$ & $-1.80(0.07)$ & $-1.30(0.15)$ \\
Lagoon & & 42 & $2.82(0.10)$ & $2.38(0.09)$ & $-2.18(0.08)$ & $-1.53(0.12)$ \\
Lagoon (WM) & & & $2.90(0.10)$ & $2.48(0.09)$ & $-2.27(0.07)$ & $-1.60(0.08)$ \\
\hline
\end{tabular}

\section{RESULTS}

\section{pH and TA evolution}

Calculated $\mathrm{pH}$ values in the enclosed water, at ambient temperature, ranged from $8.152-8.367$ at the beginning to 8.119-8.315 at the end of the incubation Values of the slope of the regression lines of $\mathrm{pH}$ versus time ranged from -0.006 to $-0.027 \mathrm{pH}$ unit $\mathrm{h}^{-1}$. TA increased from $2.310-2.402$ at initial time to 2.319-2.414 $\mathrm{mEq} \mathrm{l}^{-1}$ at final time. TA flux values ranged from 0.00 to $2.76 \mathrm{mEq} \mathrm{m} \mathrm{m}^{-2} \mathrm{~h}^{-1}$ with a mean value of $0.86 \mathrm{mEq} \mathrm{m}^{-2} \mathrm{~h}^{-1}$.

\section{$\mathrm{CO}_{2}$ and $\mathrm{O}_{2}$ fluxes}

$\Delta \mathrm{CO}_{2}$ and $\Delta \mathrm{CO}_{2}{ }^{\circ}$ ranged from 0.96 to 5.17 and from 0.96 to $4.67 \mathrm{mmol} \mathrm{m}^{-2} \mathrm{~h}^{-1}$ respectively. $\Delta \mathrm{O}_{2}$ and $\Delta \mathrm{O}_{2}{ }^{\circ}$ ranged from 0.87 to 4.38 and 0.50 to $3.27 \mathrm{mmol} \mathrm{m}^{-2} \mathrm{~h}^{-1}$ respectively. The mean values of each flux (Table 1) were significantly different for the 3 bottom types (ANOVA, $p<0.001$ ). The highest values were recorded at grey-sand bottom stations and the lowest values at mud deposit stations (multiple range test) as expected from macrobenthos (Chardy \& Clavier 1988a) and microbenthos (Boucher \& Clavier 1990) biomasses.

\section{Community respiratory quotient}

The ratio estimates from regression lines of $\Delta \mathrm{CO}_{2}{ }^{\circ}$ on $\Delta \mathrm{O}_{2}$ and $\Delta \mathrm{CO}_{2}{ }^{\circ}$ on $\Delta \mathrm{O}_{2}{ }^{\circ}$ (Fig. 2a, b), which were the slopes of the functional regressions, were calculated for the 3 bottom types and for the whole lagoon (Table 2). The slopes are not significantly different for the 3 bottom types indicating that a mean value can be applied for the whole lagoon.
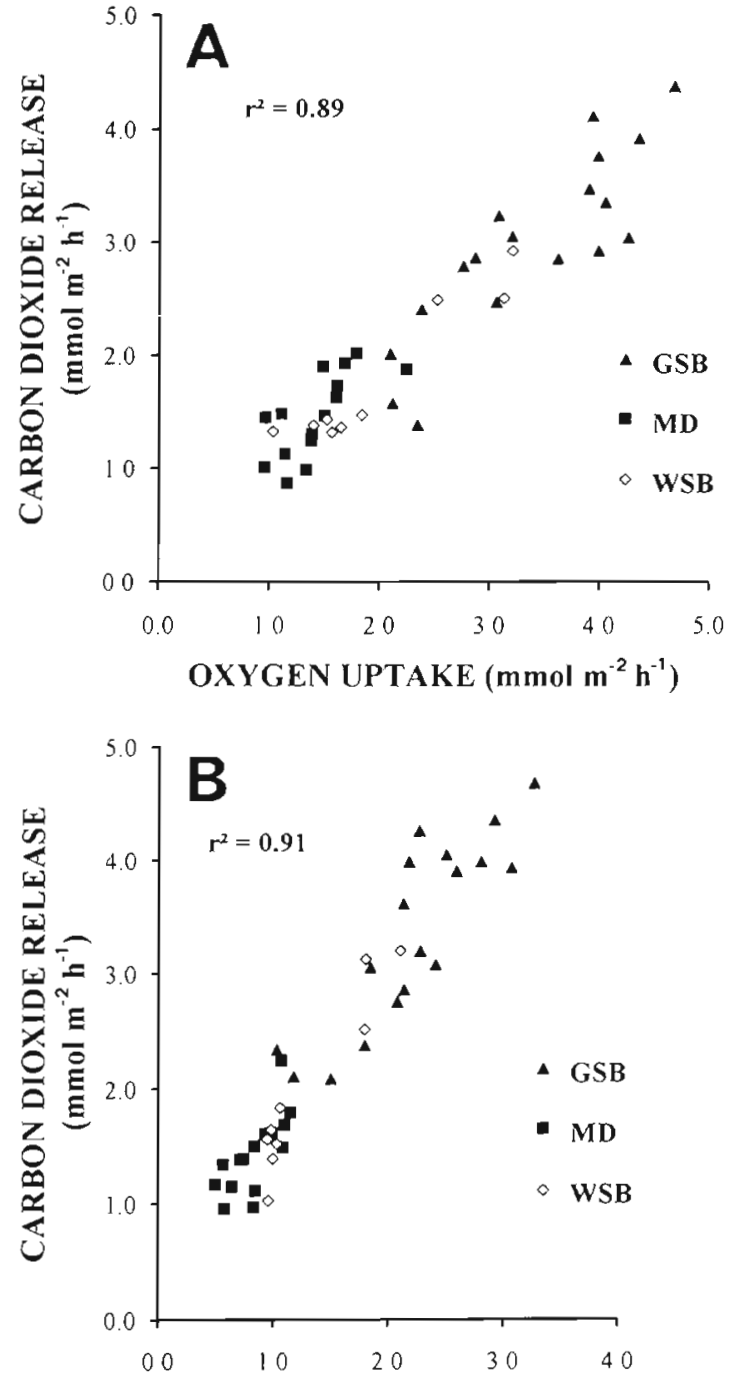

OXYGEN UPTAKE $\left(\mathrm{mmol} \mathrm{m}^{-2} \mathrm{~h}^{-1}\right)$

Fig. 2. Relationship between organic carbon dioxide release and oxygen uptake at the 3 different bottom types (MD: mud deposits; GSB: grey-sand bottom; WSB: white-sand bottom); $\mathrm{r}^{2}=0.909$. (A) Relation with total oxygen demand $\left(\Delta \mathrm{O}_{2}\right)_{i}$ (B) Relation with biological oxygen demand $\left(\Delta \mathrm{O}_{2}{ }^{\circ}\right)$ 
Table 2. Values of $C R Q$ and $C R Q^{\circ}$ (standard error in parentheses) calculated by GM regression for mud deposits (MD), grey-sand bottoms (GSB), white-sand bottoms (WSB) and the whole southwest lagoon of New Caledonia. $r^{2}=$ (correlation coefficient $)^{2}$

\begin{tabular}{|lcccc|}
\hline Community & $\mathrm{r}^{2}$ & $\mathrm{CRQ}$ & $\mathrm{r}^{2}$ & $\mathrm{CRQ}^{\circ}$ \\
\hline MD & 0.52 & $0.92(0.16)$ & 0.52 & $1.60(0.31)$ \\
GSB & 0.75 & $1.00(0.13)$ & 0.75 & $1.34(0.17)$ \\
WSB & 0.90 & $1.22(0.14)$ & 0.90 & $1.68(0.20)$ \\
Lagoon & 0.89 & $1.17(0.06)$ & 0.91 & $1.42(0.07)$ \\
\hline
\end{tabular}

\section{Aerobic and anaerobic metabolism proportions}

The percentage of NBOD was higher at muddy bottom stations $(42 \%, \mathrm{n}=5)$ than at other stations $(25 \%, \mathrm{n}=4$ and $27 \%, \mathrm{n}=5$ for grey-sand and whitesand bottoms respectively), as predicted from the silt content and organically reduced compounds in the sediment at these stations (Boucher \& Clavier 1990). $\mathrm{CRQ}^{\circ}$, calculated with oxygen fluxes corrected from NBOD, was notably higher than CRQ (Table 2). The value of the aerobic respiratory quotient (RQ) is required to calculate the proportion of anaerobic metabolism (ANQ). As the composition of the metabolic substrate is unknown in the lagoon sediment, the actual value of $R Q$ cannot be calculated. A theoretical simulation of the anaerobic quotient variation (ANQ) with the variation of $R Q$ therefore illustrates the decrease of the proportion of anaerobic metabolism when organic matter composition shifts from lipids to carbohydrates as the only metabolic substrate (Fig. 3).

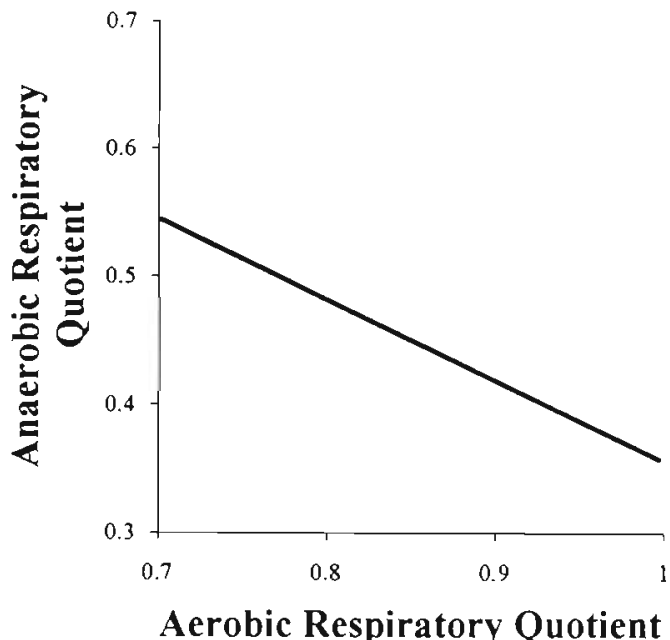

Fig. 3. Values of the anaerobic respiratory quotient metabolisms for the range of theoretical respiratory quotients for the whole southwest lagoon of New Caledonia
With a mean value of respiratory quotient $(R Q=0.85)$ based on aerobic respiration of animals and the chemical composition of organic matter proposed in the literature (Hargrave 1973), the proportion of anaerobic metabolism corresponds to $47,35,49$ and $40 \%$ of total metabolism for muddy, grey-sand, white-sand bottoms and for the whole lagoon respectively.

\section{DISCUSSION}

\section{Significance of CRQ}

Most investigations have reported a CRQ in subtidal sediments of between 1 (Teal \& Kanwisher 1961, Raine \& Patching 1980, Anderson et al. 1986) and 4 (Hargrave \& Phillips 1981, Andersen \& Hargrave 1984, Kepkay \& Andersen 1985, Oviatt et al. 1986). CRQ estimates depend on the method used for calculating the ratio. Most papers which report on metabolic ratios summarize data using arithmetic means. This practice is not valid for use with ratios where the numerator and denominator are conceptually interchangeable and geometric mean regression has to be used (Hatcher 1989). The quotient value also varies according to the interpretation of the numerator and denominator. Some authors calculated the quotient as the ratio of total carbon dioxide production to total oxygen demand (Granéli 1979, Oviatt et al. 1986) while others corrected total carbon dioxide flux from calcification processes (Sournia et al. 1981, Chisholm et al. 1990). We calculated $C R Q$ as the slope of the functional regression line of $\Delta \mathrm{CO}_{2}^{\circ}\left(\Delta \mathrm{CO}_{2}\right.$ corrected from alkalinity shift) on $\Delta \mathrm{O}_{2}$ (total oxygen demand) at the watersediment interface. This quotient has been used to assess the relative importance of anaerobic decomposition in the metabolism of benthic systems (Hargrave \& Phillips 1981) but it is more convenient to consider the ratio as a conversion factor for correcting oxygen to carbon for ecosystem measures of metabolism (1.17) for the whole southwest lagoon of New Caledonia.

Under aerobic conditions, both $\mathrm{CO}_{2}$ and $\mathrm{O}_{2}$ fluxes are closely coupled processes which are not influenced by temperature because $Q_{10}$ is similar for $\mathrm{CO}_{2}$ production and oxygen demand (Granéli 1979). However, the absence of coupling between carbon dioxide and oxygen metabolism observed in some anaerobic lakes indicates that $C R Q$ can depend more upon redox potential in the environment than on the quality of the respired substrate or on the composition of the consumers (Rich 1975). Microcosm experiments (Oviatt et al. 1986) have also shown that system metabolic ratios based on daily data can be erratic but, when based on integrated data, they are highly correlated and independent of the nutrient gradient. 
Andersen \& Hargrave (1984) proposed a method for correcting total oxygen demand from chemical oxygen uptake in order to calculate aerobic respiration, whereas they considered release of carbon dioxide in the dark as an integrated measure of aerobic respiration, nitrate and sulphate respiration and methanogenesis. In our study, the resulting ratio $\left(\mathrm{CRQ}^{\circ}=1.42\right.$ for the whole lagoon), which is always greater than CRQ, involves direct biological processes and allows the respective contribution of anaerobic and aerobic metabolisms to be calculated.

Organic carbon dioxide production and total oxygen demand are both influenced by aerobic and anaerobic processes. Carbon dioxide or bicarbonate production occurs in oxidised sediment as well as within zones of nitrate, sulphate and carbonate reduction. Demand for molecular oxygen results from biological activity and from the oxidation of reduced compounds buried in the sediment. Typical aerobic organisms display an $R Q$ of between 0.7 (minimal theoretical value) for lipids and 1 for carbohydrates (Gnaiger 1983). The range of theoretical ratios of total carbonate production to electron acceptor consumption, resulting from decay of model organic substances of different carbohydrate/lipid proportion $\left(\mathrm{CH}_{2} \mathrm{O}\right)_{x-2}\left(\mathrm{NHCH}_{2} \mathrm{CO}\right)$ or $\left(\mathrm{CH}_{2}\right)_{x-2}\left(\mathrm{NHCH}_{2} \mathrm{CO}\right)$ with different $x=\mathrm{C} / \mathrm{N}$ ratio $(6.6<x<26)$, can even be broader: 0.63 to 1.05 (Anderson et al. 1986). Unexplained variations in the $R Q$ numerator and denominator can give values outside the theoretical limits. This has been attributed to the fact that $\Delta \mathrm{CO}_{2}$ and $\Delta \mathrm{O}_{2}$ measurements were taken at different times and to substrate switching during catabolism, metabolic ratios summarising data using arithmetic means (Hatcher 1989) or to sediment disturbance (Andersen \& Kristensen 1988). In our experiment, both fluxes were measured simultaneously on undisturbed sediment and the short duration of the incubations (a few hours) does not justify the hypothesis of substrate switching.

CRQ of benthic communities does not mean the same thing as RQ of a group of aerobes only (Pamatmat 1975) as the benthos is a mixture of aerobes and anaerobes, of heterotrophs and chemoautotrophs. A ratio greater than 0.85 , which corresponds to aerobic decomposition of living tissues, indicated that more oxidised carbon leaves the sediment than enters it and that sediment has acquired an 'oxygen debt' (Pamatmat 1971, Wetzel et al. 1972), which can be fuelled by particulate sedimentation. $\mathrm{A}$ high $C R Q$ characterises a non-steady-state sediment showing anaerobic metabolism without simultaneous oxidation of the reduced metabolic products at the sediment surface. Values around 1 indicate that the bound and soluble pools of reduced metabolic products are close to steady state (Andersen \& Kristensen 1988). Until now, the observation that in situ $\mathrm{CO}_{2}$ release exceeded oxygen uptake of subtidal sediments (Hargrave \& Phillips 1981) was explained only with anaerobic respiration processes since $\mathrm{CO}_{2}$ is the end product of all aerobic and anaerobic metabolism.

\section{Factors affecting $\mathrm{CO}_{2}$ fluxes}

Many metabolic processes in a benthic community may modify the flux of carbon dioxide without simultaneous oxygen demand or affect the proportion of organic and inorganic carbon dioxide.

Sulphate reduction is quantitatively the most important process for anaerobic carbon cycling in marine sediments (Howarth 1984, Mackin \& Swider 1989, Kristensen et al. 1991) whereas nitrate reduction, fermentations and methanogenesis are of minor importance (Kaplan et al. 1979). Liberation of $\mathrm{CO}_{2}$ can be enhanced by chemical action on carbonate by organic acids produced by fermentation processes (Kerner 1993). Carbon uptake, in the form of $\mathrm{CO}_{2}$, by chemoautotrophic bacteria is variable and $\mathrm{CO}_{2}$ assimilation by sulphide-oxidising chemoautotronhs, or the uptake of roots, has been demonstrated in mangroves (Kristensen et al. 1991), a situation which could occur in grey-sand seagrass beds.

Part of particulate organic carbon deposition can be transformed in a few hours (Garber 1984) and released at the water-sediment interface as end products other than carbon dioxide, such as methane, but also as small organic molecules (dissolved free amino acids, sugar and organic acids). Methane production can be ignored in most marine situations since aerobic oxidation at the interface immediately converts the upward methane flux into $\mathrm{CO}_{2}$ (Kuivila \& Murray 1984). Organic carbon release was not measured in our study, despite a high particulate organic matter deposition $\left(0.76 \mathrm{~g} \mathrm{C} \mathrm{m}^{-2} \mathrm{~h}^{-1}\right)$ of refractory material ( $\mathrm{C} / \mathrm{N}=26$ : Clavier et al. in press). Previous data on dissolved organic nitrogen (DON) fluxes measured at the same stations (Boucher \& Clavier 1990) indicate that DON uptake predominates at muddy and white-sand stations while moderate release occurs at grey-sand stations. These fluxes could support the dissolved organic carbon (DOC) sink hypothesis (Boto et al. 1989), most organic carbon deposition being buried as refractory product or recycled by benthic organisms. The low DOC release measured from subtropical sediments (Jørgensen et al. 1981, Boto et al. 1989), despite a high concentration gradient of DOC between pore waters and overlying waters, suggests that carbon dioxide can be considered as the major end product of organic matter degradation.

The estimation of the TA correction factor applied to $\Delta \mathrm{CO}_{2}$ in order to calculate $\Delta \mathrm{CO}_{2}{ }^{\circ}$ is certainly one of the 
more important limiting factors for an estimation of carbon cycling during the course of sediment incubations. The amount of oxygen equivalents required for the production of total carbonate depends on the organic matter composition, but it is generally assumed that the $\mathrm{C} / \mathrm{N}$ ratio has a negligible effect on the production of alkalinity (Kuivila \& Murray 1984). It is well established that calcification, which occurs in oxic conditions, lowers the total $\mathrm{CO}_{2}$ content of seawater $1 \mathrm{~mol}$ for each mole of $\mathrm{CaCO}_{3}$ precipitated and that the total $\mathrm{CO}_{2}$ content of seawater is lowered by $0.5 \mathrm{~mol}$ for each equivalent of $T A$ reduction or the reverse reaction for dissolution (Smith \& Key 1975). The observed positive TA fluxes $(0.85 \mathrm{mEq}$ $\mathrm{m}^{-2} \mathrm{~h}^{-1}$ ) measured in our dark incubations could explain a dissolution of $\mathrm{CaCO}_{3}$ ranging from 0.00 to $1.40 \mathrm{mmol}$ $\mathrm{CaCO}_{3} \mathrm{~m}^{-2} \mathrm{~h}^{-1}$ at the different stations, if the whole TA shift was attributed to decalcification processes. Release is significantly higher in white-sand bottoms than in grey-sand bottoms and muddy bottoms (ANOVA: p < 0.001 ). Carbonate sands are characterised by 2 thanatocoenoses (foraminifer tests: Stns 12 \& 14, and mollusc shells: Stn 13). The lowest TA shift was measured at muddy stations where some resuspension occurred, indicating that sample filtration was efficient enough to retain fine $\mathrm{CaCO}_{3}$ particles suspended in the enclosed water (multiple range analysis denoting a significant difference). In grey-sand stations, biomass of calcareous

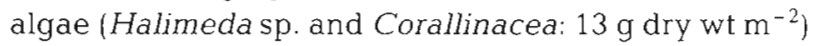
and of free cnidarians (Heteropsammia cochlea: up to $2.39 \mathrm{~g} \mathrm{dry}^{\mathrm{w}} \mathrm{m}^{-2)}$ was large enough to produce significant calcification at Stns $6,7 \& 8$, but dark calcification processes never exceeded passive sediment $\mathrm{CaCO}_{3}$ solution, even when calcifying organisms were present in large quantities.

A part of the observed TA shifts is probably related to oxidation of reduced substances at the sediment surface which produces alkalinity as well. Previous investigations, in suboxic conditions such as those simulated in our short-term incubations, have demonstrated negligible calcium diffusion related to $\mathrm{CaCO}_{3}$ dissolution in the bottom water (Balzer \& Wefer 1981, Anderson et al. 1986), but it is expected that calcium exchange should be more important in coral sands than in terrigeneous substrate from temperate areas. A significant contribution of sulphate reduction should produce about 2 times more alkalinity for an equivalent amount of oxygen acceptor than calcification processes (Balzer et al. 1983, Anderson et al. 1986). $\Delta \mathrm{CO}_{2}{ }^{\circ}$ calculated in the present study is thus probably underestimated.

\section{Factors affecting oxygen demand}

Biological oxygen demand corresponds to the $\mathrm{O}_{2}$ consumed by aerobic organisms and by chemo- lithotrophs, which use $\mathrm{O}_{2}$ both for carbon oxidation and for chemical oxidation of reduced compounds. The stoichiometry varies with the organisms involved and the physiochemical conditions. Nonbiological oxygen demand is equivalent to direct inorganic chemical oxidation of reduced compounds stored in the sediment. Although different poisons can give different estimations of NBOD, neutralized formalin poisoning gives a rough estimation of direct inorganic chemical oxidation of reduced compounds accumulated in the sediment. Although the significance of formalin poisoning has been questioned (Dale 1979, Van Es 1982), because this chemical is an oxidant and it interferes with several processes involved in oxygen and carbon dioxide production and consumption, the technique remains the easiest way to estimate nonbiological activity. Our experiments indicated a linear oxygen demand following formalin injection suggesting immediate inhibition of biological activity in the deeper layers of the sediment. Varying proportions of chemical and biological oxygen uptake were measured according to bottom type because environmental and biological conditions were significantly different (Boucher \& Clavier 1990). The proportion of NBOD measured at muddy bottom stations $(42 \%)$ compares favourably with the highest records $(60$ to $70 \%)$ found in silty anoxic sediments of salt marshes (Teal \& Kanwisher 1961, Pamatmat 1971, Dale 1979). The lower proportions of NBOD found at grey-sand and white-sand bottom stations are in the upper range, or even greater, than those previously measured in temperate coarser sediments (Smith et al. 1972, 1973, Smith 1973).

\section{Anaerobic/total metabolism proportion}

Benthic systems are fuelled by the deposition of allochthonous organic matter and the autochthonous primary production at the water-sediment interface. Labile compounds are immediately degraded at the interface by aerobic processes while refractory materials are buried in the deeper layers of the sediment, where they undergo anaerobic decomposition. We propose a simple method for calculating the proportion of anaerobic to total metabolism based on sediment organic matter composition (RQ), carbon dioxide, TA, biological and nonbiological oxygen demand measurements. For the whole southwest lagoon, the mean ratio of anoxic/total metabolism calculated for a $R Q=0.85$ indicates that aerobic metabolism is 1.5 times greater than anaerobic metabolism. An increase of the lipid:carbohydrate ratio in marine sediment will increase the proportion of anaerobic metabolism. These estimates are compatible with the calculations which identify the different metabolic pathways of 
organic matter degradation in marine sediments (Anderson et al. 1986, Kerner 1993). Anaerobic metabolism is of the same order of magnitude in mud deposits and white-sand bottoms ( 47 and $49 \%$ respectively) and higher than in grey-sand bottoms (35\%). It is anticipated that anaerobic metabolism results from refractory organic matter accumulation according to processes which are different in coastal zones and back-reef bottoms. In mud deposits, anaerobic metabolism is stimulated by an increased deposition of particulate organic matter (Clavier et al. in press) whereas in white-sand bottoms, these metabolisms result from end products of biomass degradation (small food web and primary production: Boucher \& Clavier 1990). The lower proportion of anaerobic metabolism observed in grey-sand bottoms does not indicate what happens in these sediments because macrophytes are aerobic and their contribution to total metabolism reduces apparent anaerobiosis.

\section{CONCLUSIONS}

The close correlation between carbon dioxide release and oxygen demand at the water-sediment interface confirms that $\mathrm{CO}_{2}$ and $\mathrm{O}_{2}$ fluxes are closely coupled processes in lagoon sediments. Simultaneously measuring both fluxes in the field on undisturbed communities allows an assessment of a realistic benthic metabolic quotient. The pH/alkalinity method, coupled with oxygen uptake recording, allows a reasonable indirect estimate to be made of the organic and mineral carbon flux in the field on an undisturbed sulphate-reducing sediment system. Future studies should refine the method by taking into account the proportion of organic matter constituents and the calcium flux at the water-sediment interface which would allow an estimation of the proportion of TA flux related to anaerobic metabolism (Anderson et al. 1986). The CRQ measured in the southwest lagoon of New Caledonia suggests a moderate excess of $\mathrm{CO}_{2}$ production on oxygen demand, even in white-sand bottoms, which has to be considered when modelling the system (Chardy \& Clavier 1988b). Such an excess suggests no organic matter depletion in lagoon sediments and has to be considered when balancing the carbon budget in coral reefs (Smith \& Kinsey 1988).

Acknowledgements. This research was supported by a 'PRCO: Programme National Récifs Coralliens' 1991 grant, with joint funding from 'Moyens mi-lourd' INSU/ORSTOM 1991, the 'BQR1040 Muséum National d'Histoire Naturelle 1991' and the ORSTOM 'Lagon' program. We gratefully acknowledge the crew of the ORSTOM OV 'Alis' for their help at sea and P. Gérard and J. L. Menou for technical assistance. The characteristics of the $\mathrm{pH}$ logger purchased from the AIMS laboratory (Townsville) were chosen with the advice of Dr J. P. Gattuso (URA CNRS 1453), E. Gill and G. Macnaughton (AIMS workshop: Electronic and Mechanical Division). We thank Dr P. J. Lambshead (Museum of Natural History, London) for correcting the English.

\section{LITERATURE CITED}

Andersen, F. O., Hargrave, B. T. (1984). Effects of Spartina detritus enrichment on aerobic/anaerobic benthic metabolism in an intertidal sediment. Mar. Ecol. Prog. Ser. 16: 161-171

Andersen, F. O., Kristensen, E. (1988). The influence of macrofauna on estuarine benthic community metabolism: a microcosm study. Mar. Biol. 99: 591-603

Anderson, L. G., Hall, P. O. J., Iverfeldt, A.., Rutgers van der Loeff, M. M., Sundby, B., Westerlund, S. T. G. (1986). Benthic respiration measured by total carbonate production. Limnol. Oceanogr. 31(2): 319-329

Balzer, W., Grasshoff, K., Dieckmann, P., Haardt, H., Petersohn, U. (1983). Redox-turnover at the sediment/water interface studied in a large bell jar system. Oceanol. Acta 6(4): $337-344$

Balzer, W., Wefer, G. (1981). Dissolution of carbonate minerals in a subtropical shallow marine environment. Mar. Chem. 10: $545-558$

Barnes, D. J (1983). Profiling coral reef productivity and calcification using pty and oxygen electrodes. J. exp. mar Biol. Ecol. 66: 149-161

Boto, K. G., Alongi, D. M., Nott, A. L. J (1989). Dissolved organic carbon-bacteria interactions at sediment-water interface in a tropical mangrove system. Mar. Ecol. Prog Ser. 51. 243-251

Boucher, G., Clavier, J. (1990). Contribution of benthic biomass to overall metabolism in New Caledonia lagoon sediments. Mar. Ecol. Prog. Ser. 64: 271-280

Chardy, P., Chevillon, P., Clavier, J. (1988). Major benthic communities of the south-west lagoon of New Caledonia Coral Reefs 7: 69-75

Chardy, P., Clavier, J. (1988a). Biomass and trophic structure of the macrobenthos in the south-west lagoon of New Caledonia. Mar. Biol. 99: 195-202

Chardy, P., Clavier, J. (1988b). An attempt to estimate the carbon budget for the south-west lagoon of New Caledonia. Proc. 6th int. Coral Reef Symp. 2: 541-546

Chisholm, J. R. M., Collingwood, J. C., Gill, E. F. (1990). A novel in situ respirometer for investigating photosynthesis and calcification in crustose coralline algae. J. exp. mar. Biol. Ecol. 141. 15-29

Chisholm, J R. M., Gattuso, J. P. (1991). Validation of the alkalinity anomaly technique for investigating calcification and photosynthesis in coral reef communities. Limnol. Oceanogr. 36(6): 1232-1239

Clavier, J., Chardy, P., Chevillon, P. (in press). Sedimentation of particulate matter in the southwest lagoon of New Caledonia. Estuar. coast. Shelf Sci.

Culberson, C., Pytkowicz, R. M., Hawley, J. E. (1970). Seawater alkalinity determination by the $\mathrm{pH}$ method. J. mar. Res. 28: 15-21

Dale, T. (1979). Total, chemical and biological oxygen consumption of the sediments in Lindaspollene, Western Norway. Mar. Biol. 49: 333-341

Garber, J. (1984). ${ }^{15} \mathrm{~N}$ tracer study of the short term fate of particulate organic nitrogen at the surface of coastal marine sediments. Mar. Ecol. Prog. Ser. 16: 89-104

Garrigue, C., Clavier, J., Boucher, G. (1992a). The use of photosynthesis inhibitor (DCMU) for in situ metabolic and 
primary production studies on soft bottom benthos. Hydrobiologia 246: 141-145

Garrigue, C., Clavier, J., Boucher, G., Gérard, P., Menou, J.-L. (1992b). Oxygen and dioxide carbon fluxes at the watersediment interface in the south-west lagoon of New Caledonia: methods and raw data. Rapp. scient. tech. Sci. Mer, Biol. mar. 62: 1-21

Gattuso, J. P., Jaubert, J. (1990). Effect of light on oxygen and carbon dioxide fluxes and on metabolic quotients measured in situ in a zooxanthellate coral. Limnol. Oceanogr. 35: $1796-1804$

Gattuso, J. P., Pichon, M., Delesalle, B., Frankignoulle, M. (1993). Community metabolism and air-sea $\mathrm{CO}_{2}$ fluxes in a coral reef ecosystem (Moorea, French Polynesia). Mar Ecol. Prog. Ser. 96: 259-267

Gnaiger, E. (1983). Appendix C. Calculation of energetic and biochemical equivalents of respiratory oxygen consumption. In: Gnaiger, E., Forstner, H. (eds.) Polarographic oxygen sensors. Aquatic and physiological applications. Springer-Verlag, Heidelberg, p. 337-345

Granéli, W. (1979). A comparison of carbon dioxide production and oxygen uptake in sediment cores from four Swedish lakes. Holarct. Ecol. 2: 51-57

Hargrave, B. T (1973). Coupling carbon flow through some pelagic and benthic communities. J. Fish. Res. Bd Can. 30: $1317-1326$

Hargrave, B. T., Phillips, G. A. (1981). Annual in situ carbon dioxide and oxygen flux across a subtidal marine sediment. Estuar. coast. Shelf Sci. 12: 725-737

Hatcher, A. (1989). RQ of benthic marine invertebrates. Mar. Biol. 102: 445-452

Howarth, R. W. (1984). The ecological significance of sulfur in the energy dynamics of salt marsh and coastal marine sediments. Biochemistry 1:5-27

Jacques, T. G., Pilson, M. E. Q. (1980). Experimental ecology of the temperate scleractinian coral Astrangia danae. I. Partition of respiration, photosynthesis and calcification between host and symbionts. Mar. Biol. 60: 167-178

Jørgensen, N. O. G. (1977). The sulfur cycle of a coastal marine sediment (Limfjorden, Denmark). Limnol. Oceanogr. 22: 814-832

Jørgensen, N. O. G., Blackburn, H. T., Henriksen, K., Bay, D. (1981). The importance of Posidonia oceanica and Cymodocea nodosa as contributors of free amino acids in water and sediments of sea grass beds. P.S.Z.N. I: Mar. Ecol. 2: $97-112$

Kaplan, W., Valeila, I., Teal, J. M. (1979). Denitrification in a salt marsh ecosystem. Limnol Oceanogr. 24: 726-734

Kepkay, P. E., Andersen, F. O. (1985). Aerobic and anaerobic metabolism of a sediment enriched with Spartina detritus. Mar. Ecol. Prog. Ser. 21: 153-161

Kerner, M. (1993). Coupling of microbial fermentation and respiration processes in an intertidal mudflat of the Elbe estuary. Limnol. Oceanogr. 38(2): 314-330

Kristensen, E., Holmer, M., Bussarawit, N. (1991). Benthic metabolism and sulfate reduction in a Southeast Asian mangrove swamp. Mar. Ecol. Prog. Ser. 73: 93-103

Kuivila, K. M., Murray, J W. (1984). Organic matter diagenesis in freshwater sediments: the alkalinity and total $\mathrm{CO}_{2}$ balance and methane production in the sediments of Lake Washington. Limnol. Oceanogr. 29(6): 1218-1230

Mackin, J. E., Swider, K. T (1989). Organic matter decomposition pathways and oxygen consumption in coastal marine sediments. J. mar. Res. 47:681-716

Marty, D., Bertrand, J. C., Caumette, P. (1988). Les métabo- lismes bactériens dans les systèmes sédimentaires marins. In: Bianchi, M., Marty, D., Bertrand, J. C., Caumette, P., Gauthier, M. (eds.) Micro-organismes dans les écosystèmes océaniques, Chap. 4. Masson, Paris, p. 101-151

Oviatt, C. A., Rudnick, D. T., Keller, A. A., Sampou, P. A., Almquist, G. $T$ (1986). A comparison of system $\left(\mathrm{O}_{2}\right.$ and $\mathrm{CO}_{2}$ ) and $\mathrm{C}-14$ measurements of metabolism in estuarine mesocosms. Mar. Ecol. Prog. Ser. 28: 57-67

Pamatmat, M. (1971). Oxygen consumption by the seabed. VI. Seasonal cycle of chemical oxidation and respiration in Puget Sound. Int. Rev. ges. Hydrobiol. 56: 769-793

Pamatmat, M. (1975). In situ metabolism of benthic communities. Cah. Biol. mar: 613-633

Pamatmat, M. (1977). Benthic community metabolism: a review and assessment of present status and outlook. In: Coull, B. (ed.) Ecology of marine benthos. Univ. South Carolina Press, Columbia, p. 89-111

Raine, R. C. T., Patching, J. W. (1980). Aspects of carbon and nitrogen cycling in a shallow marine environment. $J$. exp. mar. Biol. Ecol. 47: 127-139

Rich, P. H. (1975). Benthic metabolism of a soft-water lake. Verh. int. Verein. theor. angew. Limnol. 19: 1023-1028

Ricker, W. E. (1973). Linear regressions in fishery research. J. Fish. Res. Bd Can. 30: 409-434

Skirrow, G. (1975). The dissolved gases: carbon dioxide. In: Riley, J. P., Skirrow, G. (eds.) Chemical oceanography, 2nd edn, Vol. 2. Academic Press, London, p. 1-192

Skyring, G. W., Chambers, L. A. (1976). Biological sulphate reduction in carbonate sediments of a coral reef. Aust. J Freshwat. Res. 27: 595-602

Smith, K. L. Jr (1973). Respiration of a sublittoral community. Ecology 54(5): 1065-1075

Smith, K. L. Jr, Burns, K. A., Teal, J. M. (1972). In situ respiration of benthic communities in Castle Harbor, Bermuda. Mar. Biol. 12: 196-199

Smith, K. L. Jr, Rowe, G. T., Nichols, J. A. (1973). Benthic community respiration near the Woods Hole sewage outfall. Estuar. coast. mar. Sci. 1: 65-70

Smith, S. V., Key, G. S. (1975). Carbon dioxide and metabolism in marine environments. Limnol. Oceanogr. 20(1): 493-495

Smith, S. V., Kinsey, D. W. (1988). Why don't budgets of energy, nutrients, and carbonates always balance at the level of organisms, reefs, and tropical oceans? An overview. Mini Symposium 8: Materials budgets. Proc. 6 th int. Coral Reef Symp. 1: 115-120

Sokal, R. R., Rohlf, F. J. (1981). Biometry, 2nd edn. W. H. Freeman \& $\mathrm{Co}$, New York

Sørensen, J., Jørgensen, B. B., Revsbech, N. P. (1979). A comparison of oxygen, nitrate and sulfate respiration in coastal marine sediments. Microb. Ecol. 5: 105-115

Sournia, A., Delesalle, B., Ricard, M. (1981). Premiers bilans de production organique et de calcification d'un récif-barrière de la Polynésie Française. Oceanol. Acta 4: 423-431

Strickland, J. D. H., Parsons, T R. (1972). A practical handbook of seawater analysis. Bull. Fish. Res. Bd Can. 167: $1-311$

Teal, J. M., Kanwisher, J. (1961). Gas exchange in a Georgia salt marsh. Limnol. Oceanogr. 6: 388-399

Van Es, F. B. (1982). Community metabolism of intertidal flats in the Ems-Dollard estuary. Mar. Biol. 66: 95-108

Wetzel, R. G., Rich, P. H., Miller, M. C., Allen, H. L. (1972). Metabolism of dissolved and particulate detrital carbon in a temperate hard-water lake. Mem. Ist. Ital. Idrobiol. 29 (suppl.): $185-243$

Manuscript first received: February 24, 1993

Revised version accepted: February 8, 1994 